doi: $10.2306 /$ scienceasia1513-1874.2013.39.535

\title{
Fire spread prediction for deciduous forest fires in Northern Thailand
}

\author{
Agapol Junpen $^{\mathrm{a}, \mathrm{b}}$, Savitri Garivait ${ }^{\mathrm{a}, \mathrm{b}, *}$, Sebastien Bonnet $^{\mathrm{a}, \mathrm{b}}$, Adisak Pongpullponsak $^{\mathrm{c}}$ \\ a Joint Graduate School of Energy and Environment, King Mongkut's University of Technology Thonburi, \\ Bangkok 10140 Thailand \\ b Centre of Excellence on Energy Technology and Environment, Ministry of Education, \\ Bangkok 10140 Thailand \\ c Department of Mathematics, Faculty of Science, King Mongkut's University of Technology Thonburi, \\ Bangkok 10140 Thailand
}

*Corresponding author, e-mail: garivait_savitri@hotmail.com

Received 19 Dec 2012

Accepted 8 Jul 2013

\begin{abstract}
Predicting fire spread rates is essential in planning and deciding whether to conduct prescribed fires or suppressing forest fires. This study was conducted with the objective of developing a fire spread model for deciduous forest fires by using a simple statistical model. Test fires were conducted under a range of weather and fuel conditions to gather quantitative data on fire spreading. A series of 80 experimental fire plots were set in deciduous forests in the Northern Thailand during the forest fire seasons from 2008-2009. The factors influencing the fire spread rate, i.e., weather, fuel, and topography conditions, were measured to model the fire spread. According to the burning experiments, the fire spread rate was $0.51-2.55 \mathrm{~m} / \mathrm{min}$. Multiple nonlinear regression analyses of slope terrain, fuel load, and moisture content of fuels were found to be able to accurately predict the fire spread rate at a confidence level of $25-88 \%$. The developed model can be applied to deciduous forest fuels in other regions of Thailand. However, its use should be restricted to typical weather conditions.
\end{abstract}

KEYWORDS: fuel characteristics, forest fire management, prescribed burning, statistical model

\section{INTRODUCTION}

Forest fires are one of the major sources of gaseous and particulate emissions into the atmosphere ${ }^{1}$ and studies on air pollution and climate change have shown forest fires to be particularly prevalent during the dry season in Thailand ${ }^{2}$. Besides, fires can produce sufficient heat to modify local winds, contributing to atmospheric instability and causing cloud development ${ }^{3}$.

Today, Thailand currently faces annual air emission from forest fires during January to May with impact on respiratory health and vision, especially in the upper northern region of the country ${ }^{4}$. All fires are human-caused ${ }^{5}$, especially by rural people living near forested areas. The main reasons for setting fires include the gathering of forest non-timber products, e.g., fuel wood, bamboo, honey, mushrooms., hunting, agricultural residue burning for land clearing before the next crop, incendiary fires, and others. Nearly all forest fires in Thailand are classified as surface fires which combust only surface fuel including twigs, dead leaves, dead plants, grass, and undergrowth ${ }^{5}$.
Based on Forest Fire Statistic Reports from the Forest Fire Control Division of the Royal Forest Department (FFCD), Thailand ${ }^{6}$ over the period from 1998-2010, the total frequency of forest fires was approximately 80767 events corresponding to a burned surface area of 265472 ha. Approximately 50872 or $63 \%$ of all forest fire events occurred in the northern region of Thailand over a burned area of approximately 122688 ha, or $46 \%$ of all burned areas. Approximately $90 \%$ of all forest fire occurrences took place in deciduous forests characterized into two forest types, mixed deciduous forests and dry dipterocarp forests.

According to the land use map in Thailand, in 2000/2001, the area of mixed deciduous forest amounts to approximately 8.36 million ha or $46 \%$ of the total forest area (18.34 million ha) mainly located at 50-800 $\mathrm{m}$ height above sea level or higher. The characteristic tree species were Tectona grandis, Pterocarpus macrocarpus, Xylia xylocarpa var. kerrii, Afzelia xylocarpa, Lagerstroemia calyculata, Terminalia spp., and Vitex peduncularis. The middle layer is dominated by bamboos, with Gigantochloa albociliata, Bambusa tulda, and B. nutans ${ }^{7}$. This 
forest type has a long dry season lasting for more than four months. The low annual precipitation rate is in the range of $1200-1600 \mathrm{~mm}$. In dry season, plants lose their leaves. This forest is quite dry and forest fires always occur there. Nearly all of the trees in this forest type are quite dwarf and stunted ${ }^{8}$. The aboveground biomass (AGB) of mixed deciduous forests reviewed by Junpen ${ }^{9}$ ranged from $50-187$ tons of dry matter per ha. Next, the area of dry dipterocarp forest accounts for approximately 2.84 million ha or $16 \%$ of all forest area ${ }^{10}$ mainly located at a $50-1000$-m height above sea level. The soil is shallow with no water retention. The low annual precipitation amount ranges from $900-1200 \mathrm{~mm}$. The characteristic tree species were D. obtusifolius, D. tuberculatus, Shorea obtuse, and Shorea siamensis. The other common species are Dipterocarpus intricatus, Pterocarpus macrocarpus, Xylia xylocarpa, Canarium subulatum, Careya sphaerica, Melanorrhoea usitata, Quercus kerrii, and Aporusa villosa ${ }^{11}$. Dry dipterocarp forests contain plenty of dwarf bamboo and grass with annual forest fires every dry season ${ }^{8}$. The AGB of dry dipterocarp forests ranges from 58-268 tons of dry matter per $\mathrm{ha}^{9}$. However, the AGB of deciduous forests in the northern region of Thailand is considerably lower than other regions because the annual forest fires always occur in the same places in the northern region of the country ${ }^{12}$.

Regarding fire types of behaviour in deciduous forests, the $\mathrm{FFCD}^{5}$ has reported a surface fire spread rate ranging from $1.70-3.40 \mathrm{~m} / \mathrm{min}$ which is 1.00 $4.00 \mathrm{~m}$ of the flame height and $110-250 \mathrm{~kW} / \mathrm{m}$ of fireline intensity. The fire spread rate might be increased when forest fires occur in steep slope areas. The fire spread rate prediction is a key component in planning and decisions for conducting prescribed fires and suppressing forest fires. However, fire spread rate prediction in the area of the studies is unknown ${ }^{5,13}$.

A literature review on the surface fire spread models reveals that fire models can develop from two types of fuel: grassland and shrub land. The fire spread rate depends on three major environmental weather parameters, i.e., wind speed at ground level ${ }^{14-20}$, moisture content of fuel ${ }^{14,15,19,21}$, and moisture content of dead fuel ${ }^{17}$. Topographic factors include slope of terrain ${ }^{16,20}$ and fuel characteristics, e.g., high vegetation ${ }^{17,18}$, vegetation $\operatorname{cover}^{18}$, fuel load in the unit area ${ }^{18,19}$ and fuel size ${ }^{14}$. Based on previous studies, the environmental parameters involved in the prediction of fire spread rate have been used to design a suitably prescribed burning experiment in this study.

As a prospective study of the improvements in fire spread rate prediction, this study aimed at developing a fire spread model of deciduous forest fuels in the northern region of Thailand. Fire types of behaviour were examined under a range of weather and fuel conditions to gather quantitative data on fire spread. This study examined the possibility of describing fire spread rate by means of a simple statistical model. This method can reduce the uncertainty of the predicted results due to the differences between experimental scales and real fire scales. Moreover, the statistical model was based on experimentation conducted in real forest areas, such as wind, moisture profiles, and fuel heterogeneity.

\section{MATERIALS AND METHODS}

\section{Description of the study area}

The prescribed burning experiment was supported by Forest Fire Control Stations Chiangmai situated at Doi Suthep-Pui National Park, and operated by Protected Area Regional Office 16 Chiangmai Branch. The study area was situated in Doi Suthep, Suthep-pui National Park, which is located in the province of Chiangmai in the northern part of Thailand at a latitude of $14^{\circ} 59^{\prime}$ to $15^{\circ} 49^{\prime}$ north and a longitude $98^{\circ} 58^{\prime}$ to $99^{\circ} 28^{\prime}$ east at $130-1678 \mathrm{~m}$ above sea level. The mean annual rainfall and temperatures ranged from 800 $1000 \mathrm{~mm}$ and 24 and $34^{\circ} \mathrm{C}$, respectively ${ }^{22}$. Overall forest area was approximately $262.5 \mathrm{~km}^{2}$ which included four types of forest as mixed deciduous forests, dry dipterocarp forests, dry evergreen forests and pine and montane forests. The dominant tree species in the dry dipterocarp forest were Dipterocarpus tuberculatus, S. obtusa, S. siamensis and D. obtusifolius. The mixed deciduous forest consisted of Lagerstroemia duperreana, Terminalia mucronata, Tectona grandis, $X$. xylocarpa, and P. macrocarpus and some Bambusa membranacea and $B$. nutans. Tree densities ${ }^{23}$ were 3353 and 1166 trees/ha, respectively. The summer, rainy, and winter months were from March to May, June to November and December to February (of the following year), respectively.

The experiment was conducted by prescribed burning experiments in deciduous forest as dry dipterocarp forests and mixed deciduous forests. The experiment was set for two days per month between January and May from 2008-2009. The experiment was conducted during the day (11.00 am to $3.00 \mathrm{pm}$ ) which is the peak period of forest fire occurrences ${ }^{5}$. The experiment was set in four ranges of slope: $0-14 \%, 15-24 \%, 25-35 \%$, and $>35 \%$. There were 80 experimental fire plots ( 2 years $\times 2$ days $\times 5$ months $\times 4$ slopes $=80$ plots $)$. The models were developed by using the data from 


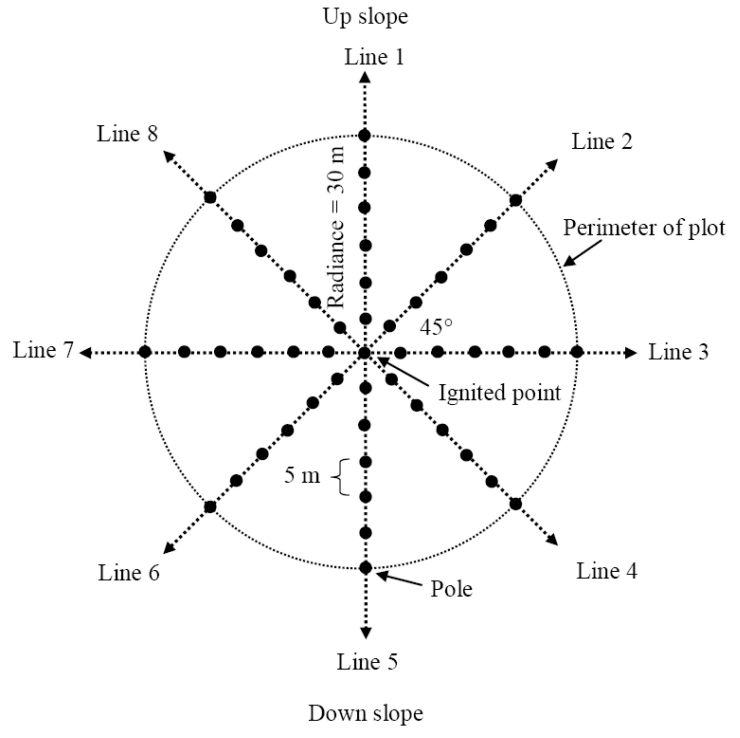

Fig. 1 Model domain and topography.

40 plots in 2008 . The models were tested by using the data from 40 plots in 2009.

\section{Experimental plot design}

The shape of the experimental plot is shown in Fig. 1. The size of the experimental plot was approximately $60 \mathrm{~m}$ in diameter on the same slope. The experimental area had never burned during the forest fire season. The centre of the experimental plot was set with 8 lines of radius which were $30 \mathrm{~m}$ long measured from the centre. The first radius line was in the upper slope. Each radius line had $45^{\circ}$. Next, the radius was divided into sections and each section was $5 \mathrm{~m}$ long. Topography characteristics, such as altitude and slope, were recorded. The altitude was measured in the centre, upper and lower areas of the sampling plot by using a global positioning system. These data were used to calculate the percent of slope. The percent of slope was calculated from the distance of the vertical height $(v)$ divided by the distance of the horizontal length $(h)$ for (percent of slope $=v / h \times 100)$.

\section{Prescribed fire experiments}

During the experiment, weather conditions (wind speed, air temperature, and air relative humidity) were recorded at $2 \mathrm{~m}$ above ground level in the open by a meteorological station placed near the experiment site. All fires were ignited in the centre of the experimental area and then the distance of the fire propagation and flame height within 8 radius lines were recorded every $2 \mathrm{~min}$. The experiment was stopped after the fire propagation had spread $30 \mathrm{~m}$ in any line. The average fire spread rate was calculated from the fire spread rates every $2 \mathrm{~min}$.

\section{Biomass fuel sampling and moisture content determination}

In the pre-experimental data records, fuel characteristics, e.g., fuel load (mass per unit area), moisture content of fuel and types of fuel, were determined from a random sample of plots located adjacent to the burning plots. The sampling plot was set at $1 \mathrm{~m} \times 1 \mathrm{~m}$ with 4 samples (in radius lines $1,3,5$, and 7) at $35 \mathrm{~m}$ from the centre of the experiment area. Fuel was then classified into four components, i.e., dead leaves, grass, twigs, and undergrowth ${ }^{5,24-26}$. Each fuel was then weighed and $100 \mathrm{~g}$ of fuel were collected for measuring moisture content by oven at $70{ }^{\circ} \mathrm{C}$ over a 48 -h period. The moisture content of biomass was calculated with the following equation: $M=(F-D) / D \times 100$, where $M$ is the percent of moisture content of biomass, $F$ is the mass of fresh biomass (g), and $D$ is the mass of dried biomass.

\section{Combustion efficiency estimation}

Post-Experimental Data Record - After the fires had been extinguished. Four sampling plots sizes were set at $1 \mathrm{~m} \times 1 \mathrm{~m}$ in the same line as the pre-experimental settings for the burned area. The remaining fuel after burning was then weighed and categorized by fuel components: dead leaves, grass, twigs, and undergrowth. These data were used to calculate the combustion efficiency (CE). The equation of the combustion efficiency is given in the following equation $^{27}: \mathrm{CE}_{i}=\left(W_{\mathrm{b} i}-W_{\mathrm{a} i}\right) / W_{\mathrm{b} i}$, where $\mathrm{CE}_{i}$ is the combustion efficiency in each fuel component $i$; dead leaves, twigs, grass and undergrowth (dimensionless), $W_{\mathrm{b} i}$ is the dry weight of the fuel component $i$ before burning $\left(\mathrm{g} / \mathrm{m}^{2}\right)$, and $W_{\mathrm{a} i}$ is the dry weight of the fuel component $i$ after burning $\left(\mathrm{g} / \mathrm{m}^{2}\right)$.

\section{Fireline intensity estimation}

The fireline intensity $(I)(\mathrm{kW} / \mathrm{m})$ was calculated by using Byram's equation ${ }^{28}: I=H W R_{\mathrm{fs}}$, where $I$ is the fireline intensity $(\mathrm{kW} / \mathrm{m}), H$ is the heating value of fuel $(\mathrm{kJ} / \mathrm{kg}), W$ is the fuel load burned $\left(\mathrm{kg} / \mathrm{m}^{2}\right)$, and $R_{\mathrm{fs}}$ is the rate of head fire spread $(\mathrm{m} / \mathrm{s})$. For deciduous forest fuels in Thailand, the heating value ${ }^{29}(H)$ is approximately $18330 \mathrm{~kJ} / \mathrm{kg}$. The fuel load burned $\left(W_{i}\right)$ was calculated from: $W_{i}=\sum_{i} W_{\mathrm{b} i} \mathrm{CE}_{i}$, where $W_{\mathrm{b} i}$ is the dry weight of the fuel component $i$ before burning $\left(\mathrm{kg} / \mathrm{m}^{2}\right)$, and $\mathrm{CE}_{i}$ is the combustion efficiency in each fuel component $i$; dead leaves, twigs, grass, and undergrowth (dimensionless). 
Table 1 Range of values for weathers, elevation, and vegetation information in the experimental plots. ${ }^{a}$

\begin{tabular}{lcccccc}
\hline & $T\left({ }^{\circ} \mathrm{C}\right)$ & $H(\%)$ & $U(\mathrm{~m} / \mathrm{min})$ & $E(\mathrm{~m})$ & $D P($ trees/plot $)$ & $D B H(\mathrm{~cm})$ \\
\hline Average & 40 & 64 & 0.4 & 387 & 22 & 41 \\
Minimum & 36 & 58 & 0.0 & 366 & 9 & 28 \\
Maximum & 45 & 75.4 & 1.6 & 438 & 51 & 63 \\
\hline
\end{tabular}

${ }^{a} T$, air temperature; $H$, air relative humidity; $U$, surface wind speed at 2 m height; $E$, elevation; $D P$, density of Perennial; and $D B H$, Diameter at breast height $(1.30 \mathrm{~m})$.

Table 2 Range of values for fire spread rate and environmental variables. ${ }^{\mathrm{a}}$

\begin{tabular}{|c|c|c|c|c|c|c|c|c|}
\hline & \multirow[t]{2}{*}{$R_{\mathrm{fs}}(\mathrm{m} / \mathrm{min})$} & \multirow[t]{2}{*}{$S(\%)$} & \multicolumn{3}{|c|}{$F$ (tons of dry matter per ha) } & \multicolumn{3}{|c|}{$M(\%)$} \\
\hline & & & $F_{\mathrm{LG}}$ & $F_{\mathrm{TU}}$ & $F_{\mathrm{O}}$ & $M_{\mathrm{LG}}$ & $M_{\mathrm{TU}}$ & $M_{\mathrm{O}}$ \\
\hline Average & 1.37 & 25.0 & 2.36 & 1.52 & 3.88 & 8.92 & 14.53 & 11.07 \\
\hline Minimum & 0.51 & 9.0 & 1.15 & 0.42 & 2.40 & 4.14 & 5.58 & 4.52 \\
\hline Maximum & 2.55 & 45.0 & 3.38 & 2.34 & 5.17 & 17.22 & 21.76 & 17.08 \\
\hline S.D. & 0.53 & 11.4 & 0.61 & 0.41 & 0.67 & 3.75 & 4.54 & 3.46 \\
\hline S.E. & 0.08 & 1.8 & 0.10 & 0.06 & 0.11 & 0.59 & 0.72 & 0.55 \\
\hline
\end{tabular}

${ }^{\text {a }} R_{\mathrm{fs}}$, rate of fire spread; $S$, percent of slope terrain; $F$, fuel load; $F_{\mathrm{LG}}$, fuel load of dead leaves and grass; $F_{\mathrm{TU}}$, fuel load of twig and undergrowth; $F_{\mathrm{O}}$, overall fuel load; $M$, moisture content of fuel; $M_{\mathrm{LG}}$, moisture content of dead leaves and grass fuel; $M_{\mathrm{TU}}$, moisture content of twig and undergrowth fuel; $M_{\mathrm{O}}$, moisture content of overall fuel.

\section{RESULTS AND DISCUSSION}

\section{Experimental plot conditions}

According to the prescribed burning experiments, fires were burned under a relatively narrow range of weather conditions. Air temperature ranged from 35$40^{\circ} \mathrm{C}$ (average $37^{\circ} \mathrm{C}$ ), air relative humidity ranged from $58-75 \%$ (average $64 \%$ ), and wind speed at ground level ranged from $0.0-0.5 \mathrm{~m} / \mathrm{s}$ or near zero. Wind speed at the ground level was very low because the experimental areas were tightly covered by high perennial trees. This situation is also associated with real forest fires. Local communities always start fires during weather conditions without wind at ground level because they prevent rapid fire spread ${ }^{5}$. The burning experiments were conducted at between 366 and $438 \mathrm{~m}$ above sea level. The tree density ranged from 9-51 trees per plot and the diameter at breast height $(1.30 \mathrm{~m})$ was from $28-63 \mathrm{~cm}$. The characteristics of weather and geographic conditions in the experimental plots are shown in Table 1.

Environmental parameters included three main parameters, i.e., weather, fuel, and topography. Only one parameter was analysed to prevent the interrelation of independent variables. In this study, the moisture content of fuel was considered as a parameter of weather; slope of terrain was considered for the parameter of topography and surface fuel load was considered for the parameter of fuels. Moreover, the moisture content of fuels and fuel load were categorized by fuel type into two groups; (1) dead leaves and grass and (2) twigs and undergrowth. The dead leaves and grass have a small size and the driest so they have direct effect on the fire propagation more than the twig and undergrowth.

Other weather parameters, such as air temperature and relative humidity (Table 1), were not the focus in this analysis because the moisture content of deciduous forest fuels is related to weather conditions, such as air temperature and relative humidity ${ }^{24}$. The above study reported air temperature to have a direct effect on the moisture content of fuels, i.e., while the air temperature is high during the daytime, fuel is more readily dried by sunlight. Relative humidity was found to have a positive relationship with the moisture content of fuels, i.e., while the relative humidity is low; the moisture content of fuel is also low, e.g., it is easy flammable with a high combustion rate and high fire intensity.

The information of environmental parameters is shown in Table 2. The area slope of the experimental plot was within a range of $9-41 \%$ of the slope. The average overall fuel load $\left(F_{\mathrm{O}}\right)$ was approximately 3.88 tons of dry matter per ha which included 2.36 tons of dry matter per ha of dead leaves and grass $\left(F_{\mathrm{LG}}\right)$ and 1.52 tons of dry matter per ha of twig and undergrowth $\left(F_{\mathrm{TU}}\right)$. The percentage of $F_{\mathrm{LG}}$ to $F_{\mathrm{O}}$ ranged from $41.2-89 \%$ (average $=60 \%$ ). The ratio of $F_{\mathrm{LG}}$ and $F_{\mathrm{TU}}$ ranged from $0.7-8.0$ (average =1.8). The moisture content of overall fuel $\left(M_{\mathrm{O}}\right)$ 
Table 3 Range of values for fire spread rate, flame height, and head fireline intensity variables. ${ }^{\text {a }}$

\begin{tabular}{|c|c|c|c|c|c|c|c|c|c|}
\hline & \multicolumn{3}{|c|}{ Rate of fire spread (m/min) } & \multicolumn{3}{|c|}{ Flame length (m) } & \multicolumn{3}{|c|}{ Fireline intensity $(\mathrm{kW} / \mathrm{m})$} \\
\hline & $H F$ & $B F$ & $F F$ & $H F$ & $B F$ & $F F$ & $H F$ & $B F$ & $F F$ \\
\hline Average & 1.37 & 0.30 & 0.46 & 1.10 & 0.40 & 0.46 & 166.30 & 36.42 & 55.84 \\
\hline Minimum & 0.51 & 0.05 & 0.13 & 0.39 & 0.18 & 0.19 & 39.33 & 3.86 & 10.03 \\
\hline Maximum & 2.55 & 0.77 & 1.05 & 2.03 & 0.73 & 1.00 & 379.79 & 114.68 & 156.38 \\
\hline S.D. & 0.53 & 0.16 & 0.21 & 0.44 & 0.14 & 0.17 & 80.32 & 24.25 & 31.82 \\
\hline S.E. & 0.08 & 0.03 & 0.03 & 0.07 & 0.02 & 0.03 & 12.70 & 4.76 & 4.76 \\
\hline
\end{tabular}

${ }^{\text {a }} H F$, head fire; $B F$, back fire; $F F$, flank fire.

Table 4 Range of values for combustion efficiency variable categorized by fuel components.

\begin{tabular}{lccccccc}
\hline & \multicolumn{7}{c}{ Combustion efficiency (dimensionless) } \\
\cline { 2 - 8 } & Dead leaves & Twig & Grass & Undergrowth & Dead leaves and grass & Twig and undergrowth & Overall Fuel \\
\hline Average & 0.98 & 0.54 & 0.94 & 0.49 & 0.98 & 0.49 & 0.80 \\
Minimum & 0.92 & 0.36 & 0.70 & 0.27 & 0.81 & 0.32 & 0.63 \\
Maximum & 1.00 & 0.75 & 1.00 & 0.66 & 1.00 & 0.71 & 0.90 \\
S.D. & 0.04 & 0.13 & 0.11 & 0.12 & 0.08 & 0.04 & 0.08 \\
S.E. & 0.01 & 0.04 & 0.04 & 0.04 & 0.02 & 0.02 \\
\hline
\end{tabular}

ranged from $4.52-17 \%$. The average moisture content of $F_{\mathrm{TU}}\left(M_{\mathrm{TU}}\right)$ was higher than $F_{\mathrm{O}}\left(M_{\mathrm{O}}\right)$ and $F_{\mathrm{LG}}$ $\left(M_{\mathrm{LG}}\right)$ because this fuel covered the undergrowth which was aboveground live biomass and the twigs retain moisture better than the dead leaves and dead grass $^{27}$.

\section{Fire types of behaviour}

The information on fire spread rate, flame height and fireline intensity at head fire (line 1), back fire (line 5) and flank fire (average of lines 3 and 7) are shown in Table 3. Fires were ignited at the centre of the experimental plots and distributed everywhere. The highest fire spread rate was at the upper slope (line 1) ranging from $0.51-2.55 \mathrm{~m} / \mathrm{min}$. The ratio head fire spread rate and back fire and flank fire spread rates were approximately $2.0-15.2$ times and 1.6-3.8 times, respectively. The steep slope area had a higher fire spread rate ratio between the head fire and the back fire. The fire spread rate of the head fire and flank fire increased with increasing slope whereas the fire spread rate of the back fire decreased with increasing slope.

\section{Combustion efficiency}

The information on the combustion efficiency categorized by fuel component is shown in Table 4 . Burning experiments showed the combustion efficiency to be dependent upon fuel components and moisture content. These results are concurrent with the study of Hoffa et $\mathrm{al}^{30}$ which reported fine and/or drier fuels to burn more completely than coarser and/or moister fuels. Comparing the combustion efficiency between deciduous forest fuels and grassland fuels investigated by Shea et $\mathrm{al}^{31}$, the same values were discovered, i.e., small fuels, e.g., dead leaves, dead grass, and live grass are almost completely burned at a combustion efficiency of approximately $0.91,0.99$ and 0.98 , respectively. Large fuels, e.g., twigs, are partially burned which a combustion efficiency of approximately 0.48 .

\section{Development of fire spread prediction}

The fire spread model was developed by using the fire spread rate at the head fire (line 1) or the line that was burned up to a 30-m distance because the head fire had a maximum fire spreading rate and fireline intensity, thus making it the most dangerous fire for forest fire control officers ${ }^{13,25}$. The information on the fire spread rate is shown in Table 2.

Correlation analysis was undertaken to investigate the relationships between fire spread rate, associated fuel characteristics and percent of slope terrain. The results are indicated in terms of a correlation matrix (Table 5). The results indicate a relationship between fire spread rate $\left(R_{\mathrm{fs}}\right)$ and slope $(S), F_{\mathrm{LG}}, F_{\mathrm{O}}, M_{\mathrm{LG}}$, and $M_{\mathrm{O}}$ (2-tailed significant $\leqslant 0.01^{* *}$ or $0.05^{*}$ ). Next, there was no relationship between $S$ and all of the fuel load parameters $\left(F_{\mathrm{LG}}, F_{\mathrm{TU}}\right.$, and $\left.F_{\mathrm{O}}\right)$. Furthermore, there was no relationship between $S$ and all of the fuel moisture content parameters $\left(M_{\mathrm{LG}}\right.$, $M_{\mathrm{TU}}$, and $M_{\mathrm{O}}$ ). However, the moisture content of 
Table 5 Correlation matrix between the variables used in the analyses., ${ }^{a}$ b

\begin{tabular}{|c|c|c|c|c|c|c|c|c|c|}
\hline & & $R_{\mathrm{fs}}$ & $S$ & $F_{\mathrm{LG}}$ & $F_{\mathrm{TU}}$ & $F_{\mathrm{O}}$ & $M_{\mathrm{LG}}$ & $M_{\mathrm{TU}}$ & $M_{\mathrm{O}}$ \\
\hline \multirow[t]{2}{*}{$R_{\mathrm{fs}}$} & $r$ & 1 & & & & & & & \\
\hline & Sig. & - & & & & & & & \\
\hline \multirow[t]{2}{*}{$S$} & $r$ & $0.596^{* *}$ & 1 & & & & & & \\
\hline & Sig. & 0.000 & - & & & & & & \\
\hline \multirow[t]{2}{*}{$F_{\mathrm{LG}}$} & $r$ & $0.659^{* *}$ & -0.110 & 1 & & & & & \\
\hline & Sig. & 0.000 & 0.947 & - & & & & & \\
\hline \multirow[t]{2}{*}{$F_{\mathrm{TU}}$} & $r$ & -0.203 & -0.016 & -0.167 & 1 & & & & \\
\hline & Sig. & 0.209 & 0.921 & 0.304 & - & & & & \\
\hline \multirow[t]{2}{*}{$F_{\mathrm{O}}$} & $r$ & $0.449^{* *}$ & -0.046 & $0.768^{* *}$ & $0.455^{* *}$ & 1 & & & \\
\hline & Sig. & 0.004 & 0.776 & 0.000 & 0.003 & - & & & \\
\hline \multirow[t]{2}{*}{$M_{\mathrm{LG}}$} & $r$ & $-0.801^{* *}$ & -0.185 & $-0.707^{* *}$ & 0.171 & $-0.513^{* *}$ & 1 & & \\
\hline & Sig. & 0.000 & 0.252 & 0.000 & 0.290 & 0.001 & - & & \\
\hline \multirow[t]{2}{*}{$M_{\mathrm{TU}}$} & $r$ & -0.170 & 0.031 & -0.247 & 0.167 & -0.158 & 0.309 & 1 & \\
\hline & Sig. & 0.294 & 0.850 & 0.125 & 0.302 & 0.331 & 0.052 & - & \\
\hline \multirow[t]{2}{*}{$M_{\mathrm{O}}$} & $r$ & $-0.732^{* *}$ & -0.087 & $-0.737^{* *}$ & 0.302 & $-0.483^{* *}$ & $0.875^{* * *}$ & $0.615^{* *}$ & 1 \\
\hline & Sig. & 0.000 & 0.594 & 0.000 & 0.059 & 0.002 & 0.000 & 0.000 & - \\
\hline
\end{tabular}

${ }^{a} r$, correlation coefficient; Sig., significant (2-tailed).

${ }^{\mathrm{b}}$ See Table 2 for the explanation of the symbols for the variables.

* Correlation is significant at the 0.05 level (2-tailed).

${ }^{* *}$ Correlation is significant at the 0.01 level (2-tailed).

fuel ( $M_{\mathrm{LG}}$ and $\left.M_{\mathrm{TU}}\right)$ had an inverse relationship with fuel load $\left(F_{\mathrm{LG}}\right.$ and $\left.F_{\mathrm{TU}}\right)$, so the model could be developed from only one parameter. This relationship could be explained in that, in the beginning of the forest fire season when $F_{\mathrm{LG}}$ includes only live grass, the average moisture content of $F_{\mathrm{LG}}$ remains high. In the middle of the forest fire season, weather is drying up and trees shed dead leaves. The cumulative amount of $F_{\mathrm{LG}}$ is high. The average moisture of $F_{\mathrm{LG}}$ is decreased because it includes dead dried grass and a large amount of dead leaves.

Relationship between $R_{\mathrm{fs}}$ and $S$ : The experiment demonstrated that $S$ influenced $R_{\mathrm{fs}}$. The relationships between $R_{\mathrm{fs}}$ and $S$ are closely related in a positive exponential function (Fig. 2):

$$
R_{\mathrm{fs}}=a \exp (b S) \quad\left(R^{2}=0.38\right)
$$

The estimates obtained for $a$ and $b$ were 0.732 (standard error $($ S.E. $)=0.088)$ and $0.022($ S.E. $=0.004)$. The coefficient of determination was approximately 0.38 meaning a slope described or predicted fire spread rate at a $38 \%$ confidence level. The equation demonstrates that fire can spread in an increasingly steep slope because the angle between the surface of the flames and fuel is narrow. Hence the fuel in the upper area dries and ignites quickly. This model is quite similar to the surface fire models of shrub land fuel in Spain studied by Vega et al ${ }^{16}$ which reported slope influences on fire spread rate in the form of a positive exponential function.

Relationship between $R_{\mathrm{fs}}$ and $F$ : The experiment demonstrated that $F_{\mathrm{O}}$ influenced $R_{\mathrm{fs}}$. The relationships between $R_{\mathrm{fs}}$ and $F_{\mathrm{O}}$ were related in a nonlinear equation the form of the positive exponential function:

$$
R_{\mathrm{fs}}=a \exp \left(b F_{\mathrm{O}}\right) \quad\left(R^{2}=0.25\right)
$$

The estimates obtained for $a$ and $b$ were 0.383 $($ S.E. $=0.126)$ and $0.309($ S.E. $=0.083)$. The coefficient of determination was approximately 0.25 . In the case of $F_{\mathrm{TU}}$, there was no relationship between $F_{\mathrm{TU}}$ and $R_{\mathrm{fs}}$ (2-tailed significant $>0.05$ ). Next, $F_{\mathrm{LG}}$ was able to explain fire spread rate with a nonlinear equation in the form of a positive exponential function at a $45 \%$ confidence level:

$$
R_{\mathrm{fs}}=a \exp \left(b F_{\mathrm{LG}}\right) \quad\left(R^{2}=0.45\right) .
$$

The estimated parameters were $a=0.454$ (S.E. $=$ $0.086)$ and $b=0.436$ (S.E. $=0.078$ ). This function shows the acceleration of fire spread is greater than 0 , depending upon the amount of $F_{\mathrm{LG}}$. The higher amount of $F_{\mathrm{LG}}$ will take higher fire intensity or heat power. The heat spread can be closer to the surface of the fuels. The surrounding fuel is drier and hotter. The increasing fire spread rate is also faster. These results are similar to the research findings of Bilgili and Saglam ${ }^{18}$ who developed a surface fire spread 


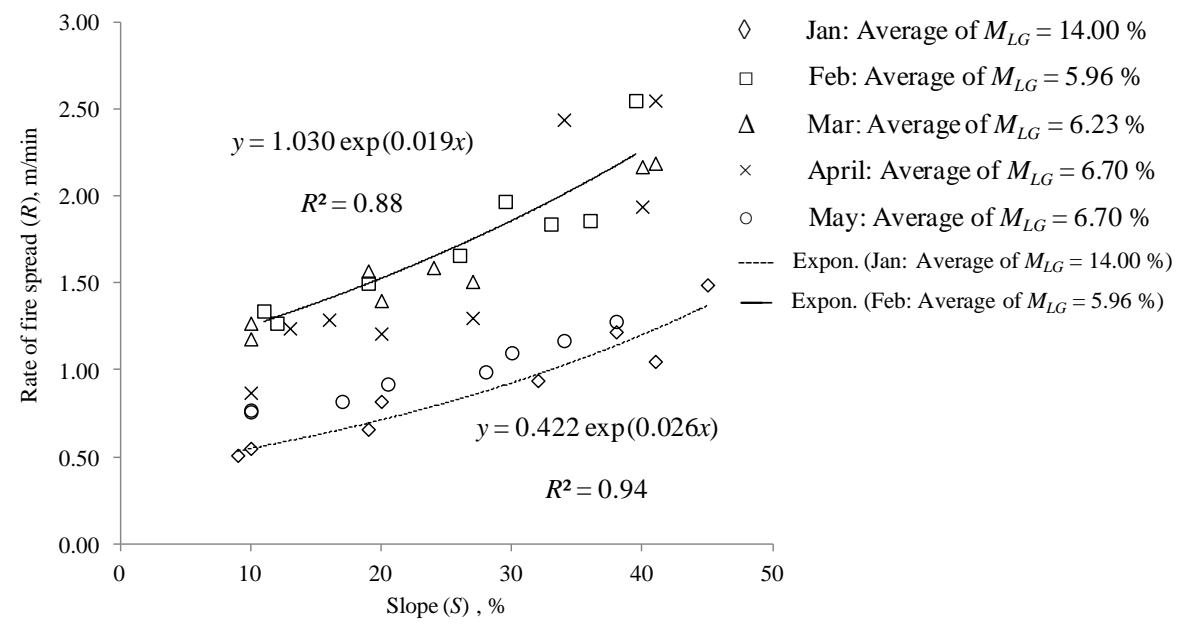

Fig. 2 Rate of fire spread categorized by group of average moisture content of dead leaves and grass fuel of each month versus slope.

model for shrub land fuels in Turkey and reported the overall fuel load to be directly related to fire spread rate in terms of positive linear function.

Relationship between $R_{\mathrm{fs}}$ and $M$ : The experiment demonstrates that $M_{\mathrm{O}}$ influences $R_{\mathrm{fs}}$. The relationships between $R_{\mathrm{fs}}$ and $M_{\mathrm{O}}$ were related in the form of a negative exponential function:

$$
R_{\mathrm{fs}}=a \exp \left(-b M_{\mathrm{O}}\right) \quad\left(R^{2}=0.45\right) .
$$

The estimates obtained for $a$ and $b$ were 2.987 (S.E. $=0.483)$ and $0.772($ S.E. $=0.014)$ in which the coefficient of determination was approximately 0.45 . $M_{\mathrm{LG}}$ was more able to explain $R_{\mathrm{fs}}$ which was related in the form of a negative exponential function at a $60 \%$ confidence level:

$$
R_{\mathrm{fs}}=a \exp \left(-b M_{\mathrm{LG}}\right) \quad\left(R^{2}=0.60\right) .
$$

The estimated parameters were $a=2.657$ (S.E. $=$ $0.280)$ and $b=0.083$ (S.E. $=0.011)$. Inversely, there was no relationship between $M_{\mathrm{TU}}$ and $R_{\mathrm{fs}}$ (2-tailed significant $>0.05)$.

Equations (2)-(5) demonstrated the fully burned fuels (small and/or dry fuels) to provide a higher confidence prediction than that of the partially burned fuels (large and/or moist fuels). This summary was supported by the studies of Fernandes ${ }^{17}$ which developed surface fire models of shrub land fuels in Portugal and Cheney et al ${ }^{15}$ which developed a model of grassland in Australia. These studies demonstrated that the moisture content of dead fuel influences fire spread rate in the form of negative exponential curves. The moisture of live fuel is not widely used for forest fire behaviour prediction and the moisture content of live fuel is normally used for crown fire spread models ${ }^{14,32}$.

Relationship between $R_{\mathrm{fs}}$ and multi-independent variables: The development of the relationship between fire spread rate $\left(R_{\mathrm{fs}}\right)$ and multi-independent variables were modelled by multiple nonlinear regression analysis. Fig. 2 shows the relationship between fire spread rates categorized by the group of average $M_{\mathrm{LG}}$ of each month (January to May) and slope of terrain. Fig. 3 shows the relationship between fire spread rates categorized by range of slope and $M_{\mathrm{LG}}$. According to Fig. 2 and Fig. 3, the variables were found to have a nonlinear relationship as a positive exponential and negative exponential function, respectively. The coefficients of equations of both graphs were used to provide the lowest value for multiple nonlinear regression analysis. Nonlinear regression analysis was used instead to fit a model of the form:

$$
R_{\mathrm{fs}}=a \exp (b S) \exp \left(-c M_{\mathrm{LG}}\right) \quad\left(R^{2}=0.88\right) .
$$

The estimated parameters were $a=1.657$ (S.E. $=$ 0.143 ), $b=0.018$ (S.E. $=0.002$ ), and $c=0.080$ (S.E. $=0.007$ ) in which the coefficient of determination was approximately 0.88 .

Next, Fig. 4 shows the relationship between fire spread rates categorized by range of slope and $F_{\mathrm{LG}}$. Fig. 5 shows the relationship between fire spread rates categorized by range of $F_{\mathrm{LG}}$ and slope of terrain. According to Fig. 4 and Fig. 5, the variables had a nonlinear relationship as a positive exponential function. Nonlinear regression analysis was used instead 


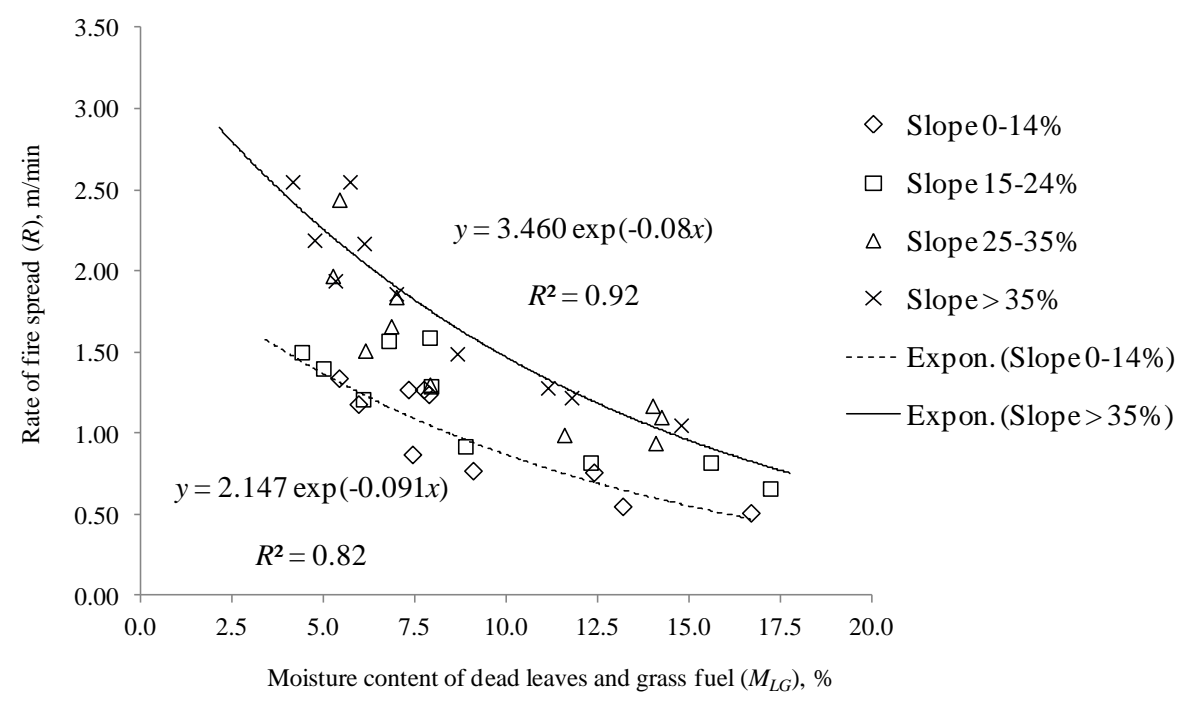

Fig. 3 Rate of fire spread categorized by range of slope versus moisture content of dead leaves and grass fuel.

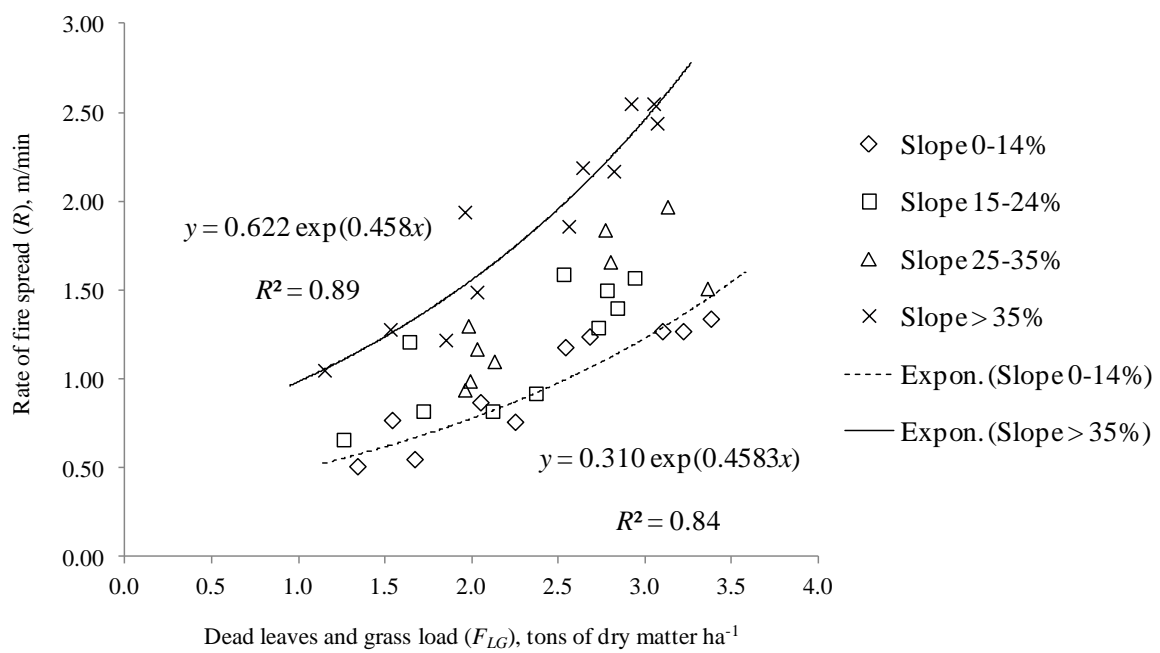

Fig. 4 Rate of fire spread categorized by range of slope versus fuel load of dead leaves and grass.

to fit the model of the form:

$$
R_{\mathrm{fs}}=\exp (b S) \exp \left(c F_{\mathrm{LG}}\right) \quad\left(R^{2}=0.87\right) .
$$

The estimated parameters were $a=0.251$ (S.E. $=$ 0.033 ), $b=0.024$ (S.E. $=0.002$ ) and $c=0.439$ (S.E. $=0.041)$ in which the coefficient of determination was approximately 0.87. According to (6) and (7), the forest areas demonstrating steep slopes and high cumulative small fuel load (dead leaves and grass) should receive greater attention than the flat slopes and low cumulative small fuel load, especially during February to April every year when the small fuel has very low moisture content.

The predicted fire spread rate plotted against the observed values from the prescribed burning experiments in 2009 show a relatively good fit (Fig. 6 and Fig. 7). The results demonstrate that the models can be used to predict fire spread rate for future situations quite well (in 2009). Notably, the predicted fire spread rates from (6) and (7) were higher than the observed fire spread rates at approximately 2.6 and $6 \%$, respectively. Hence, fire fighters have greater safety because they will realize the high propagation rate of fires.

Model application for deciduous forest in other regions: The application of (6) is suitable for other deciduous forests with fuel load of dead leaves and grass ranging from 1-4 tons of dry matter per ha (the 


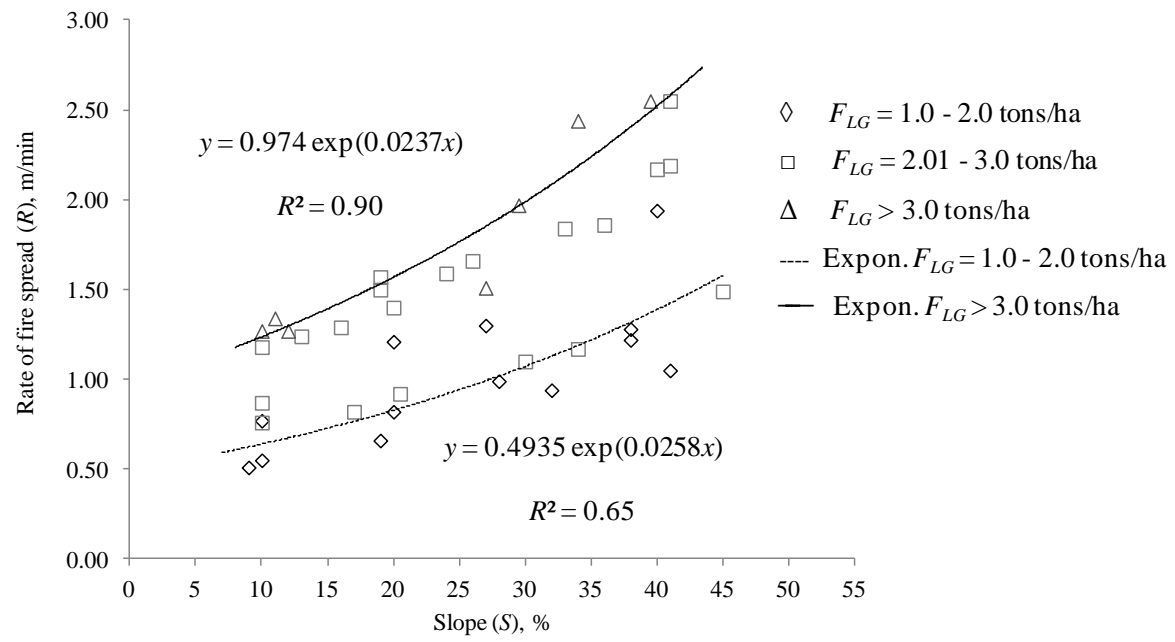

Fig. 5 Rate of fire spread categorized by range fuel load of dead leaves and grass versus slope.

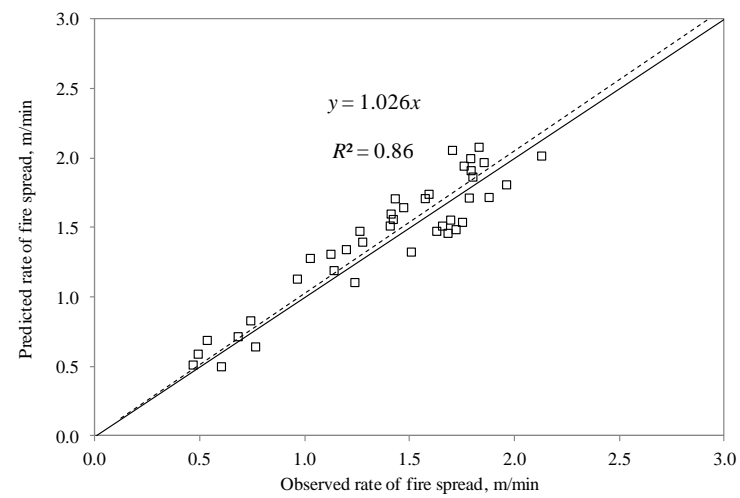

Fig. 6 Predicted versus observed rates of fire spread from the model in slope and moisture content of dead leaves and grass fuel, $R_{\mathrm{fs}}=1.657 \exp (0.018 S) \exp \left(-0.080 M_{\mathrm{LG}}\right)$, by using fire spread rate and environmental parameters information from burning experiments in 2009.

same conditions during the burning experiments). For deciduous forests where the amount of dead leaves and grass higher than 4 tons of dry matter per ha, the model provides under-estimation results. For example, in the case of the steep slope $(60 \%)$ and the low moisture content of dead leaves and grass $(5 \%)$, the predicted fire spread is no faster than $2.7 \mathrm{~m} / \mathrm{min}$.

Equation (7) has a more flexible application than (6) because the fuel load of dead leaves and grass was added to the equation. Equation (7) can be applied for the prediction of fire spread rate in deciduous forests in other regions which might have a higher dead leaves and grass load than the experimental areas. The prediction of model (7) was tested by comparing the predicted results derived by (7) with the

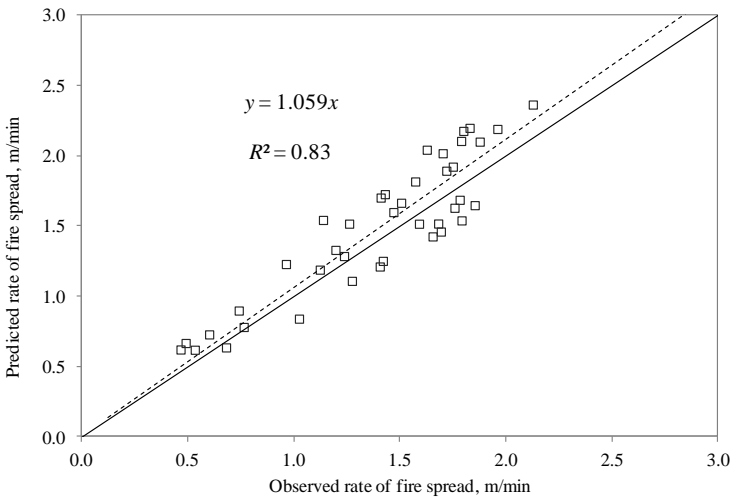

Fig. 7 Predicted versus observed rates of fire spread from the model in slope and fuel load of dead leaves and grass, $R_{\mathrm{fs}}=0.251 \exp (0.024 S) \exp \left(0.439 F_{\mathrm{LG}}\right)$, by using fire spread rate and environmental parameters information from burning experiments in 2009.

results from real forest fires observed by the $\mathrm{FFCD}^{5}$. The fire spread rates observed by the FFCD were done at major deciduous forests in four regions of Thailand including Chiangmai province in the northern region of Thailand, Kanchanaburi province in the western region, Petchburi province in the central region, and Nakornratchasrima province in the northeastern region. The method of fire spread rate and fuel characteristic measurement is quite similar to this study, except the terrain slope of real fires was not measured. Hence the value of the terrain slope was assumed within a range from $10-45 \%$ of slope which covered the terrain slope of four major deciduous forests of the FFCD data. The comparison between the predicted fire spread rate from (7) and the FFCD 
Table 6 Comparing of fire spread rate between observed and predicted for deciduous forest fuel in each region of Thailand.

\begin{tabular}{lccc}
\hline Province, Region & $\begin{array}{c}\text { Fuel load of dead leaves and grass }\left(F_{\mathrm{LG}}\right) \\
\text { (tons of dry matter per ha) })^{\dagger}\end{array}$ & $\begin{array}{c}\text { Observed } R_{\mathrm{fs}} \\
(\mathrm{m} / \mathrm{min})^{\dagger}\end{array}$ & $\begin{array}{c}\text { Predicted } R_{\mathrm{fs}} \\
(\mathrm{m} / \mathrm{min})^{\ddagger}\end{array}$ \\
\hline Chiangmai, Northern & 3.46 & 1.72 & $1.46-3.38$ \\
Kanchanaburi, Western & 3.39 & 2.81 & $1.41-3.27$ \\
Petchaburi, Central & 3.42 & 3.09 & $1.43-3.32$ \\
Nakornrachasima, North-eastern & 4.65 & 3.41 & $2.46-5.69$ \\
\hline
\end{tabular}

${ }^{\dagger}$ Observed fire spread rate from the burning experiment of $\mathrm{FFCD}^{5}$ in deciduous forests in each region of Thailand.

* Predicted fire spread rate from the model in slope of terrain and fuel load of dead leaves and grass, $R_{\mathrm{fs}}=$ $0.251 \exp (0.024 S) \exp \left(0.439 F_{\mathrm{LG}}\right)$. The value of slope was assessed in the range of $10-45 \%$ of slope.

data is shown in Table 6. The results demonstrate the fire spread rate measured from real forest fires in four regions can be comprehensively predicted by (7). Hence this model might be used to replace the deficient fire spread model for deciduous forest fires in Thailand.

\section{CONCLUSIONS}

The prescribed burning experiment based on point source ignition provides more understanding of the forest fire behaviour in deciduous forest fuels. The statistical models demonstrate five parameters influencing the fire spread rate prediction, including the moisture content of overall fuel, the moisture content of dead leaves and grass fuel, the overall fuel load, the fuel load of dead leaves and grass and slope of terrain. The combination of these parameters can accurately predict the fire spread rate at a $25-88 \%$ confidence level. However, the models should be used in areas with similar fuel characteristics and weather conditions.

For future perspective work, the effects of wind speed and direction at ground level should be added to further studies because some of the forested areas in Thailand are disturbed deciduous forests which have a low percentage of tree cover. Hence wind speed and direction have a significant influence on the increase of fire spread rates. Moreover, the effects of the aspect of slope, surface soil humidity, fuel thickness, coverage of surface fuel and amount of aboveground biomass could be investigated in the fire spread model.

Acknowledgements: This work was supported by the Higher Education Research Promotion and National Research University Project of Thailand, Office of the Higher Education Commission. The author grateful to The Joint Graduate School of Energy and Environment for research fund. Thanks for the cooperation of the Forest Fire Control Division National Park and fire fighters for supporting the experiment in this study.

\section{REFERENCES}

1. Yamasoe MA, Artaxo P, Miguel AH, Allen AG (2000) Chemical composition of aerosol particles from direct emissions of vegetation fires in the Amazon Basin: water soluble species and trace elements. Atmos Environ 34, 1641-53.

2. Crutzen PJ, Andreae MO (1990) Biomass burning in the tropics: Impacts on atmospheric chemistry and biogeochemical cycles. Science 250, 1678-9.

3. Pyne SJ, Andrews PL, Laven RD (1996) Introduction to Wildland Fire, 2nd edn, NY John Wiley \& Sons, New York.

4. Pollution Control Department (2012) Thailand State of Pollution Report 2010. Pollution Control Department, Bangkok, Thailand. [Available online at infofile.pcd. go.th/mgt/Report_Eng2553.pdf].

5. Forest Fire Control Division (2011) Forest Fire Description. National Park, Wildlife and Plant Conservation Department, Thailand. [Available online at www. dnp.go.th/forestfire/Eng/description.htm].

6. Forest Fire Control Division (2011) Forest Fire Statistics. National Park, Wildlife and Plant Conservation Department, Thailand. [Available online at www.dnp. go.th/forestfire/2546/firestatistic\%20Th.htm, in Thai].

7. Marod D, Kutintara U, Yarwudhi C, Tanaka H, Nakashisuka T (1999) Structural dynamics of a natural mixed deciduous forest in western Thailand. J Vegetation Sci 10, 777-86.

8. Royal Forest Department (2011) Forestry ContentOur Forestry-Types of Forests. [Available online at www.forest.go.th/index.php?option=com_content\&id= 311, in Thai].

9. Junpen A (2011) Spatial and temporal variation of biomass open burning emission estimation by using remote sensing information. PhD thesis, King Mongkut's Univ of Technology Thonburi, Thailand.

10. Land Development Department (2011) Summary of Land Use of Thailand in 2000/2001.

11. Thai Long-Term Forest Ecological Research (2013) Canopy Structure of the Dry Dipterocarp Forest of Thailand.

12. Boonrodklab C, Teejuntuk S (2008) Structure and aboveground biomass of forest community in Doi 
Inthanon National Park, Chiang Mai province. In: Proceedings of 46th Kasetsart Univ Annual Conference, Architecture and Engineering and Natural Resources and Environment Department of Silviculture, Faculty of Forestry, Kasetsart Univ, Thailand.

13. Pastor E, Zárate L, Planas E, Arnaldos J (2003) Mathematical models and calculation systems for the study of wildland fire behaviour. Progr Energ Combust Sci 29, 139-53.

14. Forestry Canada Fire Danger Group (1992) Development and Structure of the Canadian Forest Fire Behavior Prediction System. Forestry Canada, Information Report ST-X-3, Ottawa.

15. Cheney NP, Gould JS, Catchpole WR (1998) Prediction of fire spread in grasslands. Int $J$ Wildland Fire 8, 1-13.

16. Vega JA, Cuiñas P, Fontúrbel T, Pérez-Gorostiaga P, Fernández C (1998) Predicting fire behaviour in Galician (NW Spain) shrubland fuel complexes. In: Viegas DX (ed) Proceedings of the 3rd International Conference on Forest Fire Research/14th Fire and Forest Meteorology Conference, Luso, ADAI, Univ of Coimbra, Coimbra, pp 713-28.

17. Fernandes PAM (2001) Fire spread prediction in shrub fuels in Portugal. Forest Ecol Manag 144, 67-74.

18. Bilgili E, Saglam B (2003) Fire behavior in maquis fuels in Turkey. Forest Ecol Manag 184, 201-7.

19. Burrows ND, Ward B, Robinson AD, Behn G (2006) Fuel dynamics and fire behaviour in spinifex grasslands of the western desert. In: Bushfire Conference 2006, Brisbane, Australia.

20. Boboulos M, Purvis MRI (2009) Wind and slope effects on ROS during the fire propagation in EastMediterranean pine forest litter. Fire Saf J 44, 764-9.

21. Beaza MJ, et al (2002) Factors influencing fire behaviour in shrublands of different stand ages and the implications for using prescribed burning to reduce wildfire risk. J Environ Manag 65, 199-208.

22. Thai Meteorological Department of Thailand (2011) Thailand Annual Weather Summary.

23. Khamyong N (2009) Plant species diversity, soil characteristics and carbon accumulation in different forests, Doi Suthep-Pui National Park, Chiang Mai province. MSc thesis, (Agriculture) Soil Science, Chiang Mai Univ, Thailand.

24. Akaakara S, Viriya K, Tongton T (2003) Fire Behaviors in Dry Dipterocarp Forest at Huai Kha Khaeng Wildlife Sanctuary. Forest Fire Control Division, National Park, Wildfire and Plant Conservation Department, Thailand.

25. Akaakara S, Viriya K, Tongton T, Nhuchaiya P (2004) Fuel Characteristics in Dry Dipterocarp Forest at Huai Kha Khaeng Wildlife Sanctuary. Forest Fire Control Division, National Park, Wildfire and Plant Conservation Department, Thailand.

26. Garivait S, et al (2007) Monitoring and Assessment of Air Pollutant Emissions from Forest Fires in the Northern Region of Thailand. National Research Council, Thailand.
27. Seiler W, Crutzen PJ (1980) Estimates of gross and net fluxes of carbon between the biosphere and the atmosphere from biomass burning. Clim Change 2, 207-47.

28. Byram GM (1959) Combustion of forest fuels. In: Davis KP (ed) Forest Fire Control and Use. McGrawHill, New York, pp 61-89.

29. Sompoh B (1998) Fuel complex in dry dipterocarp and mixed deciduous forests at Huai Kha Khaeng Wildlife Sanctuary Changwat Uthai Thani. MSc thesis, Faculty of Forestry, Kasetsart Univ, Thailand, pp 68-70.

30. Hoffa EF, et al (1999) Seasonality of carbon emissions from biomass burning in a Zambian savanna. J Geophys Res 104, 13841-53.

31. Shea RW, et al (1996) Fuel biomass and combustion factors associated with fires in savanna ecosystems of South Africa and Zambia. J Geophys Res 101, 23551-68.

32. Rothermel RC (1972) A Mathematical Model for Predicting Fire Spread in Wildland Fuels. Intermountain Forest and Range Experiment Station, Forest Service U.S. Department of Agriculture, Ogden, Utah. 